Article

\title{
Chemical Constituents of the Leaves of Peltophorum pterocarpum and Their Bioactivity
}

\author{
Yue-Chiun Li ${ }^{1}$, Ping-Chung Kuo ${ }^{2, *} \mathbb{D}$, Mei-Lin Yang ${ }^{3}$, Tzu-Yu Chen ${ }^{3}$, Tsong-Long Hwang ${ }^{4,5,6} \mathbb{D}^{\mathbb{D}}$, \\ Chih-Chao Chiang ${ }^{7}$, Tran Dinh Thang ${ }^{8,9}$, Nguyen Ngoc Tuan ${ }^{10}$ and Jason T.C. Tzen ${ }^{1, *}$ \\ 1 Graduate Institute of Biotechnology, National Chung-Hsing University, Taichung 402, Taiwan; \\ ycli0126@gmail.com \\ 2 School of Pharmacy, College of Medicine, National Cheng Kung University, Tainan 701, Taiwan \\ 3 Department of Biotechnology, National Formosa University, Yunlin 632, Taiwan; \\ L3891104@nckualumni.org.tw (M.-L.Y.); black4635@gmail.com (T.-Y.C.) \\ 4 Graduate Institute of Natural Products, College of Medicine, Chang Gung University, Taoyuan 333, Taiwan; \\ htl@mail.cgu.edu.tw \\ 5 Research Center for Industry of Human Ecology, Research Center for Chinese Herbal Medicine, \\ and Graduate Institute of Health Industry Technology, Chang Gung University of Science and Technology, \\ Taoyuan 333, Taiwan \\ 6 Department of Anesthesiology, Chang Gung Memorial Hospital, Taoyuan 333, Taiwan \\ 7 Graduate Institute of Clinical Medical Sciences, College of Medicine, Chang Gung University, Taoyuan 333, \\ Taiwan; moonlight0604@hotmail.com \\ 8 School of Chemistry, Biology and Environment, Vinh University, Vinh City 43159, Vietnam; \\ thangtd@vinhuni.edu.vn \\ 9 NTT Institute of High Technology, Nguyen Tat Thanh University, Ho Chi Minh City 72820, Vietnam \\ 10 Institute of Biotechnology and Food Technology, Industrial University of Ho Chi Minh City, \\ Ho Chi Minh City 71408, Vietnam; nguyenngoctuan@iuh.edu.vn \\ * Correspondence: z10502016@email.ncku.edu.tw (P.-C.K.); tctzen@dragon.nchu.edu.tw (J.T.C.T.); \\ Tel.: +886-6-2353535 (ext. 6806) (P.-C.K.); +886-4-22840328 (J.T.C.T.)
}

Academic Editor: Ericsson Coy-Barrera

Received: 20 December 2018; Accepted: 9 January 2019; Published: 10 January 2019

Abstract: Two new sesquiterpenoids peltopterins A and B (compounds 1 and 2) and fifty-two known compounds were isolated from the methanol extract of $P$. pterocarpum and their chemical structures were established through spectroscopic and mass spectrometric analyses. The isolates 40, 43, 44, 47, 48, 51 and 52 exhibited potential inhibitory effects of superoxide anion generation or elastase release.

Keywords: Fabaceae; sesquiterpenoid; superoxide anion generation; elastase release

\section{Introduction}

Peltophorum pterocarpum (DC.) Backer ex K. Heyne (Fabaceae) is a deciduous tree originated from the tropical regions, ex. Sri Lanka, the Andamans, the Malay Peninsula and North Australia [1]. Traditionally, its flowers are used for slowing intestinal diseases and childbirth pain, treating muscle sprains, bruises, swelling and pain [2]. Roots and barks are also used to cure abdominal colic, joint and back pain, and ascites [3]. Reports on Peltophorum species have described antibacterial [4,5], antifungal [6,7], antivirus [8,9], antioxidant [10], antitumor [10,11], deworming [12,13], hypoglycemic [2,14], cardiotonic [15], hepatoprotective [16] and leukoagglutinating bioactivities [17]. However, there are only a few studies related to the chemical composition of the Peltophorum species. A preliminary examination showed that the methanol extract and fractions of leaves of P. pterocarpum displayed significant superoxide anion and elastase inhibition at $10 \mu \mathrm{g} / \mathrm{mL}$ (Table 1). Therefore, we sought to purify the constituents from the leaf extract and 
examine the anti-inflammatory potential of the isolated compounds to identify new anti-inflammatory leads from natural sources. In this study the chemical profiles of leaves of P. pterocarpum were comprehensively investigated and a total of fifty-four compounds were identified. Among these, two new sesquiterpenoids 1 and $\mathbf{2}$ were characterized and the structures were established by spectroscopic and spectrometric analyses. In addition, the purified compounds were examined for their superoxide anion and elastase inhibitory effects.

Table 1. Inhibition of P. pterocarpum leave extract and fractions on superoxide anion generation and elastase release in human neutrophils.

\begin{tabular}{ccc}
\hline \multirow{2}{*}{ Samples } & \multicolumn{2}{c}{ Inhibition Percentage (\%) } \\
\cline { 2 - 3 } & Superoxide Anion Generation & Elastase Release \\
\hline Methanol extract & $53.4 \pm 4.3^{* * *}$ & $112.3 \pm 5.0^{* * *}$ \\
Chloroform fraction & $60.7 \pm 5.9^{* * *}$ & $113.6 \pm 5.9^{* * *}$ \\
Water fraction & $49.4 \pm 0.7^{* * *}$ & $50.8 \pm 5.0^{* * *}$ \\
\hline
\end{tabular}

a Percentage of inhibition (Inh \%) at $10 \mu \mathrm{g} / \mathrm{mL}$ concentration. Results are presented as mean \pm S.E.M. $(n=3)$. *** $p<0.001$ compared with the control value.

\section{Results and Discussion}

\subsection{Isoaltion and Identification}

Air-dried and powdered leaves of P. pterocarpum were refluxed with methanol, and the combined extracts were concentrated in vacuo to produce a brownish syrup. This syrup was suspended into water and partitioned with chloroform to afford a chloroform layer and a water soluble fraction respectively. After isolation using a combination of continuous conventional chromatographic techniques, two new compounds, named peltopterins A (1) and B (2), were isolated and their structures established by nuclear magnetic resonance (NMR) and mass spectrometric analyses. Moreover, fifty-two known compounds, including six sesquiterepnoids: rel-5-(3S,8S-dihydroxy-1R,5S-dimethyl-7-oxa-6-oxobicyclo[3,2,1]-oct-8-yl)-3-methyl-2Z,4E-pentadienoic acid (3) [18], 3,6-dihydroxy-5,6-dihydro- $\beta$-ionol (4) [19], (-)-boscialin (5) [20], (3S,5R,6R,7E,9S)-3,5,6,9-tetrahydroxy-7-megastigmene (6) [21], 2,6,6-trimethyl-4-oxo-2-cyclohexene-1-acetic acid (7) [22], (3S,5R,6S,9S)-megastigmane-3,9,13-triol (8) [23]; nine benzenoids, $p$-hydroxybenzoic acid (9) [24], isovanillic acid (10) [25], trans-methyl p-coumarate (11) [24], trans-ferulic acid (12) [26], methyl ferulate (13) [27], benzoic acid (14) [28], vanillic acid (15) [29], syringic acid (16) [30], sodium salicylate (17) [31]; two coumarins: scopoletin (18) [32], scopolin (19) [33]; two lignans: dihydrodehydrodiconiferyl alcohol (20) [34], $\left(7^{\prime} S, 8^{\prime} R\right)-7^{\prime}, 8^{\prime}$-dihydro-8'-hydroxymethyl-3-hydroxy-7'-(4'-hydroxy-3'-methoxyphenyl)-1-benzofuranpropanol 9'-O- $\beta$-D-glucoside (21) [18]; one alkaloid: 4(1H)-quinolinone (22) [35]; one diterpene: 3(17)-phytene 1,2-diol (23) [36]; thirteen steroids: a mixture of $\beta$-sitosterol (24) and stigmasterol (25) [37,38], a mixture of 6 6 -hydroxystigmast-4-en-3-one (26) and 6 $\beta$-hydroxystigmasta-4,22-dien-3-one

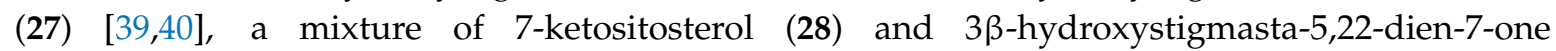
(29) [41,42], a mixture of stigmast-4-en-3-one (30) and stigmast-4,22-dien-3-one (31) [43,44], $\beta$-sitosteryl-3-O- $\beta$-D-glucoside (32) [45], ergosterol peroxide (33) [46], ergosta-4,6,8(14),22-tetraen-3-one (34) [47], 9,11-dehydroergosterol peroxide (35) [48], 20-hydroxy-ecdysone (36) [49]; six triterpenes: friedelin (37) [50], lupenone (38) [51], 24,25-dihydrocimicifugeuol

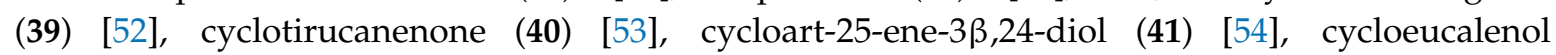
(42) [55]; and twelve flavonoids: kaempferol 3-O- $\alpha$-L-rhamnoside (43) [56], quercetin 3-O- $\alpha$-L-rhamnoside (44) [57], kaempferol 3-O- $\beta$-D-glucoside (45) [58], kaempferol 3-rutinoside (46) [59], quercetin 3-O- $\beta$-D-glucoside (47) [57], quercetin 3-O- $\alpha$-L-arabinofuranoside (48) $[60], \quad$ kaempferol 3 -O-[ $\alpha$-L-rhamno-pyranosyl $(1 \rightarrow 6)]-\beta$-D-galactopyranoside (49) $[61], \quad$ kaempferol $3-O-[\alpha$-L-rhamnopyranosyl $(1 \rightarrow 3)]-\beta$-D-glucopyranoside 
(50) [62], quercetin 3-O-[ $\alpha$-L-rhamnopyranosyl $(1 \rightarrow 3)]-\beta$-D-glucopyranoside quercetin 3-O-[ $\alpha$-L-rhamnopyranosyl $(1 \rightarrow 2)]-\beta$-D-xylopyranoside (52) [64],

[51) [63], 3-O-[ $\alpha$-L-rhamnopyranosyl $(1 \rightarrow 2)]-\beta$-D-xylopyranoside [65], kaempferol 3-O-[ $\alpha$-L-rhamnopyranosyl- $(1 \rightarrow 2)-\alpha$-L-rhamnopyranosyl $(1 \rightarrow 6)]-\beta$-D-galactopyranoside $(54)[66]$ respectively, were characterized by comparison of their physical and spectroscopic data with those published previously.

\subsection{Structural Determination of $\mathbf{1}$ and $\mathbf{2}$}

Compound 1 was obtained as white powder with m.p. $116-118{ }^{\circ} \mathrm{C}$ and $[\alpha]_{\mathrm{D}}{ }^{25}=-73$. The molecular formula was determined as $\mathrm{C}_{11} \mathrm{H}_{18} \mathrm{O}_{3}$ by a sodium adduct ion peak at $m / z 221.1150$ in high resolution electrospray ionization mass spectrometry (HR-ESI-MS) analysis. The infrared (IR) absorption bands at 3430 and $1709 \mathrm{~cm}^{-1}$ corresponded with the presence of a hydroxy and a carbonyl groups, respectively. In its ${ }^{1} \mathrm{H}-\mathrm{NMR}$ analysis, there were proton signals for two methyl singlets at $\delta$ $0.87\left(3 \mathrm{H}, \mathrm{CH}_{3}-11\right)$ and $0.95\left(3 \mathrm{H}, \mathrm{CH}_{3}-10\right)$, one methylene group at $\delta 2.20(1 \mathrm{H}, \mathrm{dd}, J=18.1,12.2 \mathrm{~Hz}, \mathrm{H}-7)$ and $2.68(1 \mathrm{H}, \mathrm{dd}, J=18.1,5.6 \mathrm{~Hz}, \mathrm{H}-7)$, two oxymethylene protons at $\delta 3.88(1 \mathrm{H}, \mathrm{m}, \mathrm{H}-9 \mathrm{a})$ and 4.34 $(1 \mathrm{H}, \mathrm{dd}, J=11.1,4.8 \mathrm{~Hz}, \mathrm{H}-9 \mathrm{~b})$, one oxymethine at $\delta 3.88(1 \mathrm{H}, \mathrm{m}, \mathrm{H}-3)$, and two methines at $\delta 1.21$ $(1 \mathrm{H}, \mathrm{dd}, J=12.1,6.7 \mathrm{~Hz}, \mathrm{H}-2)$ and $0.89(1 \mathrm{H}, \mathrm{m}, \mathrm{H}-4)$. The ${ }^{13} \mathrm{C}-\mathrm{NMR}$ and distortionless enhancement by polarization transfer (DEPT) spectra exhibited a ester carbonyl signal at $\delta 171.2(\mathrm{C}-8)$, two methyl carbons at $\delta 20.2$ (C-11) and 29.2 (C-10), four methylene carbons at $\delta 30.8$ (C-7), 36.8 (C-4), 50.0 (C-2) and 73.8 (C-9), three methines at $\delta 32.3$ (C-5), 44.2 (C-6) and 65.8 (C-3), and a quaternary carbon at $\delta 34.0$ (C-1). The correlation spectroscopy (COSY) correlations of $\mathrm{H}-2 / \mathrm{H}-3 / \mathrm{H}-4, \mathrm{H}-5 / \mathrm{H}-6 / \mathrm{H}-7$, and $\mathrm{H}-9 / \mathrm{H}-5$ suggested the presence of the partial structures $-\mathrm{CH}_{2} \mathrm{CH}(\mathrm{OH}) \mathrm{CH}_{2-},-\mathrm{CH}_{2} \mathrm{CHCH-}$, and $-\mathrm{CHCH}_{2-}$, respectively. The ${ }^{2} \mathrm{~J}$ - and ${ }^{3} \mathrm{~J}$-correlations from $\mathrm{H}-2$ to $\mathrm{C}-4, \mathrm{C}-6, \mathrm{C}-10$, and C-11; from $\mathrm{H}-3$ to C-5; from H-6 to C-5 and C-9; from H-7 to C-1, C-5, and C-8; and from H-9 to C-4, C-5, and C-8, respectively, could be observed in the heteronuclear multiple bond correlation (HMBC) spectrum (Figure 1). According to these spectral analyses and the index of hydrogen deficiency (IHD = 3), it indicated the presence of two rings and a carbonyl group in $\mathbf{1}$ and these analytical results constructed the planar structure of $\mathbf{1}$ (Figure 1). Furthermore, the coupling pattern of full width at half maximum (FWHM) of H-3 $(12.3 \mathrm{~Hz})$ revealed its axial orientation. The nuclear overhauser effect spectroscopy (NOESY) showed NOE correlations between H-3 and H-5 but no correlations were observed between H-5 and H-6. These experimental data established the relative stereochemistry configuration of $\mathbf{1}$ as shown (Figure 1) and assigned the trivial name peltopterin A.
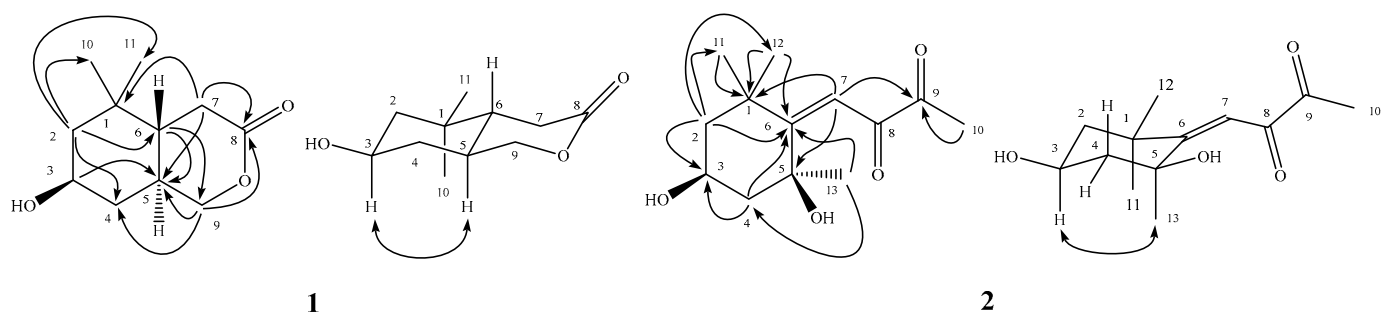

2

Figure 1. Significant $\operatorname{HMBC}(\rightarrow)$ and $\operatorname{NOESY}(\leftrightarrow)$ correlations of $\mathbf{1}$ and 2.

Peltopterin B (2) was assigned a molecular formula of $\mathrm{C}_{13} \mathrm{H}_{20} \mathrm{O}_{4}$ from HR-ESI-MS analysis. The ultraviolet (UV) absorption maxima at $232 \mathrm{~nm}$ and the IR absorption bands at 3414 and 1677 $\mathrm{cm}^{-1}$ indicated the occurrence of hydroxyl and conjugated carbonyl groups. The ${ }^{1} \mathrm{H}-\mathrm{NMR}$ spectrum of 2 revealed signals for one vinyl proton at $\delta 5.84(1 \mathrm{H}, \mathrm{s}, \mathrm{H}-7)$; four methyl singlets at $\delta 1.15(3 \mathrm{H}$, $\left.\mathrm{CH}_{3}-12\right), 1.37\left(3 \mathrm{H}, \mathrm{CH}_{3}-11\right), 1.42\left(3 \mathrm{H}, \mathrm{CH}_{3}-13\right)$ and $2.17\left(3 \mathrm{H}, \mathrm{CH}_{3}-10\right)$; one oxymethine at $\delta 4.33(1 \mathrm{H}$, dddd, $J=11.5,11.5,4.0,4.0 \mathrm{~Hz}, \mathrm{H}-3)$; and two methylene groups at $\delta 1.36(1 \mathrm{H}, \mathrm{m}, \mathrm{H}-2 \mathrm{ax}), 1.43(1 \mathrm{H}$, $\left.\mathrm{m}, \mathrm{H}-4_{\mathrm{ax}}\right), 1.98\left(1 \mathrm{H}, \mathrm{ddd}, J=11.5,4.0,2.5 \mathrm{~Hz}, \mathrm{H}-2_{\mathrm{eq}}\right)$, and $2.29\left(1 \mathrm{H}, \mathrm{ddd}, J=11.5,4.0,2.5 \mathrm{~Hz}, \mathrm{H}-4_{\mathrm{eq}}\right)$. The ${ }^{13}$ C-NMR spectrum also displayed two carbonyl signals at $\delta 198.5$ (C-9) and 209.8 (C-8), three methyl carbons at $\delta 26.5(\mathrm{C}-10), 29.2(\mathrm{C}-11)$, and 31.1 (C-13), two methylene carbons at $\delta 49.1(\mathrm{C}-2)$ and 
48.8 (C-4), two methines at $\delta 63.4$ (C-3) and 100.9 (C-7), and four quaternary carbons at $\delta 36.3$ (C-1), 72.5 (C-5), 118.6 (C-6), and 31.8 (C-12), respectively. The ${ }^{2} J$ - and ${ }^{3} J$-HMBC correlations from H-2 to C-3, C-6, C-11, and C-12; from H-4 to C-3, and C-6; from H-7 to C-1, C-5, C-6 and C-9; from $\mathrm{CH}_{3}-10$ to C-9; from $\mathrm{CH}_{3}-11$ to $\mathrm{C}-1$; from $\mathrm{CH}_{3}-12$ to $\mathrm{C}-1$ and $\mathrm{C}-6$; and from $\mathrm{CH}_{3}-13$ to $\mathrm{C}-4$ and $\mathrm{C}-6$, respectively, evidenced the planar structure of 2 as (3,5-dihydroxy-1,1,5-trimethylcyclohexylidene)butan-8,9-dione (Figure 1). The NOE correlation between $\mathrm{H}-3$ and $\mathrm{CH}_{3}-13$ (see Supplementary Materials) determined the relative stereochemistry at C-5 (Figure 1) and the structure 2 was characterized accordingly. However, the absolute configurations of the two new compounds remained to be determined. Among the purified flavonoid glycosides, compounds $\mathbf{5 1}$ and $\mathbf{5 2}$ had been reported without NMR spectral data recorded in $\mathrm{MeOH}-d_{4}[63,64]$. In the present study, these compounds were identified through 1D and 2D NMR spectroscopic analysis and the fully assigned NMR data in MeOH- $d_{4}$ were listed in Section 3.

\subsection{Anti-inflammatory Activity}

Among these isolates, numerous compounds were selected to be evaluated for the superoxide anion generation and elastase release inhibition by human neutrophils in response to $N$-formyl-L-methionyl-phenylalanine/cytochalasin B (fMLP/CB) (Table 2).

Table 2. Superoxide anion and elastase inhibitory effects of isolated compounds in human neutrophils.

\begin{tabular}{|c|c|c|}
\hline \multirow{2}{*}{ Compound } & Superoxide Anion & Elastase \\
\hline & $\operatorname{Inh} \%^{a}$ & $\operatorname{Inh} \%^{a}$ \\
\hline 1 & $7.0 \pm 3.4$ & $-2.1 \pm 3.4$ \\
\hline 2 & $0.9 \pm 2.2$ & $1.5 \pm 3.1$ \\
\hline 3 & $2.5 \pm 1.6$ & $-2.1 \pm 3.1$ \\
\hline 4 & $5.5 \pm 0.2^{* * *}$ & $1.7 \pm 3.5$ \\
\hline 5 & $4.8 \pm 1.4^{*}$ & $8.3 \pm 1.3$ \\
\hline 6 & $5.4 \pm 0.5^{* * *}$ & $6.5 \pm 1.3^{* *}$ \\
\hline 7 & $7.2 \pm 2.5 *$ & $3.9 \pm 4.1$ \\
\hline 8 & $3.0 \pm 0.6^{* *}$ & $5.3 \pm 5.6$ \\
\hline 19 & $2.2 \pm 0.8$ & $7.5 \pm 4.1$ \\
\hline 20 & $10.6 \pm 2.6^{*}$ & $1.7 \pm 3.6$ \\
\hline 21 & $9.2 \pm 0.1 * * *$ & $9.3 \pm 2.9 *$ \\
\hline 36 & $10.4 \pm 6.9$ & $3.0 \pm 2.3$ \\
\hline 39 & $14.0 \pm 0.1^{* * *}$ & $-b$ \\
\hline 40 & $13.4 \pm 2.5^{* *}$ & $24.9 \pm 3.1^{* *}$ \\
\hline 41 & $17.1 \pm 2.3^{* *}$ & $-{ }^{b}$ \\
\hline 43 & $42.3 \pm 4.3^{* * *}$ & $22.1 \pm 6.8^{*}$ \\
\hline 44 & $48.5 \pm 1.0^{* * *}$ & $12.6 \pm 4.0$ * \\
\hline 45 & $20.4 \pm 4.2^{* *}$ & $14.6 \pm 5.9$ \\
\hline 46 & $-6.8 \pm 3.0$ & $-3.5 \pm 4.2$ \\
\hline 47 & $45.7 \pm 0.5^{* * *}$ & $22.1 \pm 5.4^{*}$ \\
\hline 48 & $44.2 \pm 4.4^{* * *}$ & $25.5 \pm 7.6^{*}$ \\
\hline 49 & $-9.1 \pm 7.5$ & $17.6 \pm 4.4^{*}$ \\
\hline 50 & $10.6 \pm 1.1^{* * *}$ & $13.2 \pm 2.7^{* *}$ \\
\hline 51 & $46.4 \pm 2.7^{* * *}$ & $15.8 \pm 3.0$ ** \\
\hline 52 & $43.7 \pm 4.9^{* * *}$ & $32.3 \pm 6.8^{* *}$ \\
\hline 53 & $6.8 \pm 2.3^{*}$ & $17.0 \pm 4.9^{*}$ \\
\hline 54 & $6.9 \pm 1.8 *$ & $18.2 \pm 2.9^{* *}$ \\
\hline
\end{tabular}

a Percentage of inhibition (Inh \%) at $10 \mu \mathrm{M}$ concentration. Results are presented as mean \pm S.E.M. $(n=3) .{ }^{*} p<0.05$, ${ }^{* *} p<0.01,{ }^{* * *} p<0.001$ compared with the control (DMSO). ${ }^{\mathrm{b}}$ The enhance of elastase release was observed at tested concentration.

The results indicated that $\mathbf{4 3}, \mathbf{4 4}, \mathbf{4 7}, \mathbf{4 8}, \mathbf{5 1}$ and $\mathbf{5 2}$ show a significant inhibition of superoxide anion generation, with the inhibitory percentages ranged from $42.3 \pm 4.3$ to $48.5 \pm 1.0 \%$ at $10 \mu \mathrm{M}$. In addition, 40, 43, 47, 48 and 52 presented inhibition of elastase release, with inhibitory percentages that ranged from $22.1 \pm 5.4$ to $32.3 \pm 6.8 \%$ at $10 \mu \mathrm{M}$. Inflammation is a defense mechanism response 
to bacteria, virus, wound or other various environmental factors resulting in injury. It is also a first response of the immune system to infection and stimulation. In response to diverse stimuli, activated neutrophils secrete a series of cytotoxins, such as superoxide anion and elastase [67]. Therefore, inhibition of superoxide anion production and elastase release in infected tissues and organs could directly modulate neutrophil pro-inflammatory responses. Therefore, the crude extract and purified constituents of P. pterocarpum have potential to be developed as new anti-inflammatory lead drugs or health food ingredients. In comparison, $\mathbf{3 9}$ and $\mathbf{4 1}$ enhanced the elastase release in CB-priming human neutrophils with values of $73.0 \pm 9.8$ and $86.8 \pm 3.0 \%$ at $10 \mu \mathrm{M}$. It had been reported that an increasing elastase release effect promoted the immune response $[68,69]$. These results are interesting for the further studies related to the bioactivity and mechanism.

\section{Materials and Methods}

\subsection{General}

All the chemicals, unless specifically indicated otherwise, were bought from Merck KGaA (Darmstadt, Germany). The melting points, optical rotations, UV and IR spectra were recorded on an MP-S3 micromelting point apparatus (Yanagimoto, Kyoto, Japan), a P-2000 digital polarimeter (Jasco, Tokyo, Japan), a U-0080D diode array spectrophotometer (Hitachi, Tokyo, Japan), and a FT-IR Spectrum RX1 spectrophotometer (PerkinElmer, Waltham, MA, USA), respectively. The ESI-MS and HR-ESI-MS spectra were obtained on a Bruker Daltonics APEX II 30e spectrometer (Bruker, Billerica, MA, USA). ${ }^{1} \mathrm{H}-,{ }^{13} \mathrm{C}-$, and all 2D NMR (COSY, NOESY, HMQC, and HMBC) spectra were recorded on Bruker AV-500 and Avance III-400 NMR spectrometers (Bruker, Billerica, MA, USA) with tetramethylsilane as the internal standard using deuterated solvents purchased from Sigma-Aldrich (St. Louis, MO, USA). Chemical shifts are reported in parts per million (ppm, $\delta$ ). Column chromatography and thin layer chromatography (TLC) were conducted on silica gels (Kieselgel 60, 70-230 mesh and 230-400 mesh) and precoated Kieselgel $60 \mathrm{~F} 254$ plates (Merck KGaA), and the compounds were detected by UV light or $10 \%(v / v) \mathrm{H}_{2} \mathrm{SO}_{4} / \mathrm{EtOH}$ reagent.

\subsection{Plant Materials}

The leaves of P. pterocarpum were collected in Vietnam (August 2009) and the plant material was authenticated by Assoc. Prof. Dr. Tran Huy Thai, Institute of Ecology and Biological Resources, Vietnamese Academy of Science and Technology.

\subsection{Extraction and Isolation}

The leaves of P. pterocarpum (dried weight $10.0 \mathrm{~kg}$ ) were powdered, refluxed with methanol and the combined extracts then concentrated in vacuo to give a brownish syrup $(1.2 \mathrm{~kg})$. The crude extract was further separated into chloroform ( $350 \mathrm{~g})$ and water soluble layers $(850 \mathrm{~g})$ by partition between chloroform and water.

The chloroform layer was purified on a silica gel column eluted with $n$-hexane and a step gradient of ethyl acetate (300:1 to 1:1) to afford nine fractions as monitored by TLC. Fraction 4 was column chromatographed on silica gel with a step gradient mixture of $n$-hexane and ethyl acetate (100:1 to 1:1) to afford 13 subfractions. Subfraction 4.2 was further purified by preparative TLC eluted with a $n$-hexane and ethyl acetate solvent mixture (100:1) to yield 38 (0.8 $\mathrm{mg}$ ) and $\mathbf{4 0}$ (4.2 mg). Subfraction 4.5 was further resolved on a silica gel column eluted with a step gradient mixture of $n$-hexane and acetone (100:1 to 1:1) to produce eight minor fractions (4.5.1-4.5.8). Minor fraction 4.5.2 was purified with pTLC using $n$-hexane and ethyl acetate (50:1) to yield $37(7.8 \mathrm{mg})$. Minor fraction 4.5.4 was isolated with silica gel column chromatography with a mixture of benzene and acetone (300:1) and further recrystallization of the resulting fractions afforded $\mathbf{2 3}(5.5 \mathrm{mg})$, a mixture of $\mathbf{2 6}$ and $\mathbf{2 7}(6.5 \mathrm{mg})$, a mixture of $\mathbf{3 0}$ and $31(4.4 \mathrm{mg}), \mathbf{3 9}(2.7 \mathrm{mg})$, and $\mathbf{4 2}(5.6 \mathrm{mg})$, respectively. Minor fraction 4.5 .7 was performed pTLC purification with a mixture of benzene and acetone (50:1) and produced 41 (4.5 $\mathrm{mg})$. 
Subfraction 4.6 was isolated by silica gel column chromatography eluted with a mixture of benzene and acetone (300:1) and further recrystallization of the minor fractions produced a mixture of 24 and $25(15.1 \mathrm{mg})$, a mixture of 28 and $29(3.2 \mathrm{mg})$, and $34(1.5 \mathrm{mg})$. Subfraction 4.7 was separated by silica gel column chromatography eluted with a chloroform and acetone solvent mixture (300:1) to yield 12 $(2.8 \mathrm{mg})$ and $35(1.5 \mathrm{mg})$. Fraction 5 was further separated by repeated column chromatography over silica gel eluted with $n$-hexane and a step gradient of acetone (200:1 to 1:1) followed by purification of the resulting subfractions by recrystallization to afford $\mathbf{1}(2.2 \mathrm{mg}), \mathbf{2}(1.6 \mathrm{mg}), \mathbf{5}(2.7 \mathrm{mg}), \mathbf{1 1}(2.2 \mathrm{mg}), \mathbf{1 8}$ $(2.2 \mathrm{mg})$, and $33(0.8 \mathrm{mg})$. Fraction 6 was subjected to silica gel column chromatography eluted with chloroform and a step gradient of methanol (200:1 to 1:1) to produce 13 subfractions. Subfraction 6.6 was further silica gel column chromatographed with a mixture of $n$-hexane and acetone (20:1) to yield $4(9.0 \mathrm{mg}), 7(4.3 \mathrm{mg})$ and $20(7.8 \mathrm{mg})$. Fraction 7 was resolved on silica gel column eluted with a step gradient mixture of chloroform and methanol (200:1 to 1:1) to give 17 subfractions. Subfraction 7.10 was further separated by silica column chromatography with a mixture of chloroform and acetone (20:1) to result in $\mathbf{1 0}(1.5 \mathrm{mg})$. Subfraction 7.11 was isolated by pTLC with a mixture of chloroform and acetone (20:1) to yield 9 (3.1 $\mathrm{mg})$.

The water soluble layer was applied to a reverse-phase Diaion HP-20 column and eluted with a step gradient of water and methanol (10:0, 7:3, 5:5, 3:7, 0:10) to afford nine fractions. Fraction 4 was further purified with Diaion HP-20 column chromatography eluted with water and a step gradient of methanol (10:0 to 0:10) to afford eight subfractions. Subfraction 4.2 was separated by Diaion HP-20 gel column chromatography as previously described to obtain nine minor fractions. The first minor fraction 4.2.1 was further purified by silica gel column chromatography with a mixture of chloroform and methanol (100:1) to produce $6(2.3 \mathrm{mg})$ and $14(4.5 \mathrm{mg})$. Minor fraction 4.2.4 was further isolated by repeated column chromatography over silica gel eluted with a step gradient mixture of ethyl acetate and methanol (100:1 to $1: 1)$ to result in $3(4.0 \mathrm{mg}), \mathbf{1 6}(2.1 \mathrm{mg}), \mathbf{1 9}(8.2 \mathrm{mg})$, and $22(4.8 \mathrm{mg})$. Minor fraction 4.2.6 was applied to pTLC with a mixture of ethyl acetate, methanol and water (30:1:0.1) to give $54(7.2 \mathrm{mg})$. Fraction 5 was resolved on Diaion HP-20 gel column eluted with water and a step gradient of methanol (10:0 to 0:10) to produce eight subfractions. Subfraction 5.4 was further purified by silica gel column chromatography with a mixture of chloroform and methanol (50:1) to yield six minor fractions. Minor fraction 5.4.1 was subjected to pTLC purification with a mixture of chloroform and methanol (100:1) to obtain $15(9.1 \mathrm{mg})$. Minor fraction 5.4.2 was further separated by silica gel column chromatography with a mixture of chloroform, methanol and water (10:1:0.1) to result in 50 (14.1 mg), $51(2.2 \mathrm{mg})$, and $52(4.9 \mathrm{mg})$. Subfraction 5.5 was separated by repeated column chromatography over silica gel eluted with a step gradient mixture of ethyl acetate and methanol (300:1 to 1:1) followed by recrystallization of the resulting minor fractions to yield $8(7.4 \mathrm{mg}), \mathbf{1 7}(1.4 \mathrm{mg}), 47(1.9 \mathrm{mg})$, and 53 $(22.4 \mathrm{mg})$. Fraction 6 was column chromatographed with Diaion HP-20 gel to give 11 subfractions. Subfraction 6.6 was purified by silica gel column chromatography eluted with a step gradient mixture of chloroform, methanol and water (100:1:0.1 to 1:1:0.1) to produce five minor fractions. Minor fraction 6.6.1 was purified by pTLC with a mixture of chloroform, methanol and water (8:1:0.1) to obtain 44 $(2.2 \mathrm{~g})$ and $48(17.3 \mathrm{mg})$. Subfraction 6.6.2 was purified by repeated column chromatography over silica gel eluted with a step gradient mixture of ethyl acetate, methanol and water (300:1:0.1 to 1:1:0.1) to yield $36(3.8 \mathrm{mg}), 45(1.5 \mathrm{mg}), 46(12.6 \mathrm{mg})$, and $49(2.8 \mathrm{mg})$. Subfraction 6.7 was further isolated by silica gel column chromatography eluted with a mixture of chloroform, methanol and water (50:1:0.1) to give six minor fractions. The minor fractions 6.7.4 and 6.7.6 were purified by pTLC with a mixture of chloroform, methanol and water (5:1:0.1) to afford 21 (1.6 mg), 43 (6.3 mg); and 13 (4.2 mg), respectively. Fraction 9 was resolved repeatedly on silica gel column chromatography eluted with a step gradient mixture of ethyl acetate and methanol (300:1 to 1:1) followed by recrystallization of the resulting fractions to obtain $32(1.5 \mathrm{mg})$. 


\subsubsection{Peltopterin A (1)}

White powder, m.p. $116-118{ }^{\circ} \mathrm{C}\left(\mathrm{CHCl}_{3}\right) ;[\alpha]_{\mathrm{D}}^{25}=-73\left(\right.$ c 0.1, $\left.\mathrm{CHCl}_{3}\right)$; IR (KBr) $v_{\max } 3430,2949$, 2924, 1709, 1469, 1299, 1239, 1219, 1092, $1026 \mathrm{~cm}^{-1}$; ESI-MS (rel. int. \%) $\mathrm{m} / \mathrm{z} 221\left([\mathrm{M}+\mathrm{Na}]^{+}, 100\right)$; HR-ESI-MS $m / z 221.1150[\mathrm{M}+\mathrm{Na}]^{+}$(calcd for $\left.\mathrm{C}_{11} \mathrm{H}_{18} \mathrm{NaO}_{3}, 221.1154\right) ;{ }^{1} \mathrm{H}-\mathrm{NMR}\left(\mathrm{CDCl}_{3}, 400 \mathrm{MHz}\right) \delta$ $4.34(1 \mathrm{H}, \mathrm{dd}, J=11.1,4.8 \mathrm{~Hz}, \mathrm{H}-9 \mathrm{~b}), 3.88(1 \mathrm{H}, \mathrm{m}, \mathrm{H}-9 \mathrm{a}), 3.88(1 \mathrm{H}, \mathrm{FWHM}=23.2 \mathrm{~Hz}, \mathrm{H}-3), 2.68(1 \mathrm{H}$, $\mathrm{dd}, J=18.1,5.6 \mathrm{~Hz}, \mathrm{H}-7), 2.20(1 \mathrm{H}, \mathrm{dd}, J=18.1,12.2 \mathrm{~Hz}, \mathrm{H}-7), 1.99(1 \mathrm{H}, \mathrm{m}, \mathrm{H}-4), 1.82(2 \mathrm{H}, \mathrm{m}, \mathrm{H}-2,5)$, $1.38(1 \mathrm{H}, \mathrm{ddd}, J=12.2,12.1,5.6 \mathrm{~Hz}, \mathrm{H}-6), 1.21(1 \mathrm{H}, \mathrm{dd}, J=12.1,6.7 \mathrm{~Hz}, \mathrm{H}-2), 0.95\left(3 \mathrm{H}, \mathrm{s}, \mathrm{CH}_{3}-10\right), 0.89$ $(1 \mathrm{H}, \mathrm{m}, \mathrm{H}-4), 0.87$ (3H, s, $\left.\mathrm{CH}_{3}-11\right) ;{ }^{13} \mathrm{C}-\mathrm{NMR}\left(\mathrm{CDCl}_{3}, 100 \mathrm{MHz}\right) \delta 171.2$ (C-8), 73.8 (C-9), 65.8 (C-3), 50.0 (C-2), 44.2 (C-6), 36.8 (C-4), 34.0 (C-1), 32.3 (C-5), 30.8 (C-7), 29.2 (C-10), 20.2 (C-11).

\subsubsection{Peltopterin B (2)}

Colorless syrup, $[\alpha]_{\mathrm{D}}^{25}=-29\left(c 0.4, \mathrm{CH}_{3} \mathrm{OH}\right) ; \mathrm{UV}(\mathrm{MeOH}) \lambda_{\max }(\log \varepsilon) 232$ (4.00) nm; IR (KBr) $v_{\max } 3417,2963,1938,1667,1455,1366,1243,1157,1040,955,820 \mathrm{~cm}^{-1}$; HR-ESI-MS $\mathrm{m} / z 241.1434$ ([M + $\mathrm{H}^{+}$) (calcd for $\left.\mathrm{C}_{13} \mathrm{H}_{21} \mathrm{O}_{4}: 241.1440\right) ;{ }^{1} \mathrm{H}-\mathrm{NMR}\left(\mathrm{CDCl}_{3}, 500 \mathrm{MHz}\right) \delta 5.84(1 \mathrm{H}, \mathrm{s}, \mathrm{H}-7), 4.33(1 \mathrm{H}, \mathrm{dddd}$, $J=11.5,11.5,4.0,4.0 \mathrm{~Hz}, \mathrm{H}-3), 2.29\left(1 \mathrm{H}, \mathrm{ddd}, J=11.5,4.0,2.5 \mathrm{~Hz}, \mathrm{H}-4_{\mathrm{eq}}\right), 2.17\left(3 \mathrm{H}, \mathrm{s}, \mathrm{CH}_{3}-10\right), 1.98(1 \mathrm{H}$, ddd, $J=11.5,4.0,2.5 \mathrm{~Hz}, \mathrm{H}-2 \mathrm{eq}), 1.43\left(1 \mathrm{H}, \mathrm{m}, \mathrm{H}-4_{\mathrm{ax}}\right), 1.42\left(3 \mathrm{H}, \mathrm{s}, \mathrm{CH}_{3}-13\right), 1.37\left(3 \mathrm{H}, \mathrm{s}, \mathrm{CH}_{3}-11\right), 1.36$ $(1 \mathrm{H}, \mathrm{m}, \mathrm{H}-2 \mathrm{ax}), 1.15\left(3 \mathrm{H}, \mathrm{s}, \mathrm{CH}_{3}-12\right) ;{ }^{13} \mathrm{C}-\mathrm{NMR}\left(\mathrm{CDCl}_{3}, 125 \mathrm{MHz}\right) \delta 209.8$ (C-8), 198.5 (C-9), 118.8 (C-6), 100.9 (C-7), 72.5 (C-5), 63.4 (C-3), 49.1 (C-2), 48.8 (C-4), 36.3 (C-1), 31.8 (C-12), 31.1 (C-13), 29.2 (C-11), $26.5(\mathrm{C}-10)$.

\subsubsection{Quercetin-3-O-[ $\alpha$-L-rhamnopyranosyl $(1 \rightarrow 3)]$ - $\beta$-D-glucopyranoside (51)}

Yellow powder; ${ }^{1} \mathrm{H}-\mathrm{NMR}\left(\mathrm{CD}_{3} \mathrm{OD}, 500 \mathrm{MHz}\right) \delta 7.69\left(1 \mathrm{H}, \mathrm{d}, J=2.0 \mathrm{~Hz}, \mathrm{H}-2^{\prime}\right), 7.58(1 \mathrm{H}, \mathrm{dd}, J=8.5$, $\left.2.0 \mathrm{~Hz}, \mathrm{H}-5^{\prime}\right), 6.87\left(1 \mathrm{H}, \mathrm{d}, J=8.5 \mathrm{~Hz}, \mathrm{H}-6^{\prime}\right), 6.35(1 \mathrm{H}, \mathrm{d}, J=2.0 \mathrm{~Hz}, \mathrm{H}-8), 6.17(1 \mathrm{H}, \mathrm{d}, J=2.0 \mathrm{~Hz}, \mathrm{H}-6)$, $5.74\left(1 \mathrm{H}, \mathrm{d}, J=7.5 \mathrm{~Hz}, \mathrm{H}-1^{\prime \prime}\right), 5.21\left(1 \mathrm{H}, \mathrm{d}, J=1.5 \mathrm{~Hz}, \mathrm{H}-1^{\prime \prime \prime}\right), 4.02\left(1 \mathrm{H}, \mathrm{dd}, J=10.0,6.5 \mathrm{~Hz}, \mathrm{H}-5^{\prime \prime \prime}\right), 3.99$ $\left(1 \mathrm{H}, \mathrm{dd}, J=3.5,1.5 \mathrm{~Hz}, \mathrm{H}-2^{\prime \prime \prime}\right), 3.96\left(1 \mathrm{H}, \mathrm{dd}, J=10.0,8.0 \mathrm{~Hz}, \mathrm{H}-3^{\prime \prime}\right), 3.85\left(1 \mathrm{H}, \mathrm{m}, \mathrm{H}-4^{\prime \prime}\right), 3.78(1 \mathrm{H}, \mathrm{dd}$, $\left.J=10.0,3.5 \mathrm{~Hz}, \mathrm{H}-3^{\prime \prime \prime}\right), 3.71\left(1 \mathrm{H}, \mathrm{dd}, J=8.0,7.5 \mathrm{~Hz}, \mathrm{H}-2^{\prime \prime}\right), 3.65\left(1 \mathrm{H}, \mathrm{dd}, J=11.5,6.0 \mathrm{~Hz}, \mathrm{H}-6^{\prime \prime} \mathrm{b}\right), 3.61$ $\left(1 \mathrm{H}, \mathrm{dd}, J=11.5,6.5 \mathrm{~Hz}, \mathrm{H}-6^{\prime \prime} \mathrm{a}\right), 3.49\left(1 \mathrm{H}, \mathrm{dd}, J=6.5,6.0 \mathrm{~Hz}, \mathrm{H}-5^{\prime \prime}\right), 3.34\left(1 \mathrm{H}, \mathrm{m}, \mathrm{H}-4^{\prime \prime \prime}\right), 0.93(3 \mathrm{H}, \mathrm{d}$, $\left.J=6.5 \mathrm{~Hz}, \mathrm{CH}_{3}-6^{\prime \prime \prime}\right) ;{ }^{13} \mathrm{C}-\mathrm{NMR}\left(\mathrm{CD}_{3} \mathrm{OD}, 125 \mathrm{MHz}\right) \delta 179.4$ (C-4), 168.8 (C-7), $163.2(\mathrm{C}-5), 158.4$ (C-9), 158.1 (C-2), $149.6\left(\mathrm{C}-4^{\prime}\right), 145.9\left(\mathrm{C}-3^{\prime}\right), 134.6(\mathrm{C}-3), 123.4\left(\mathrm{C}-6^{\prime}\right), 123.0\left(\mathrm{C}-1^{\prime}\right), 117.3\left(\mathrm{C}-2^{\prime}\right), 116.1\left(\mathrm{C}-5^{\prime}\right)$, 105.8 (C-10), $102.6\left({\left.\mathrm{C}-1^{\prime \prime \prime}\right)}^{\prime \prime}, 100.8\left(\mathrm{C}-1^{\prime \prime}\right), 99.9(\mathrm{C}-6), 94.6(\mathrm{C}-8), 77.6\left(\mathrm{C}-3^{\prime \prime}\right), 77.1\left(\mathrm{C}-5^{\prime \prime}\right), 75.8\left(\mathrm{C}-2^{\prime \prime}\right), 74.1\right.$ $\left(\mathrm{C}-4^{\prime \prime \prime}\right), 72.4\left(\mathrm{C}-3^{\prime \prime \prime}\right), 72.3\left(\mathrm{C}-2^{\prime \prime \prime}\right), 70.9\left(\mathrm{C}-4^{\prime \prime}\right), 69.9\left(\mathrm{C}-5^{\prime \prime \prime}\right), 62.1\left(\mathrm{C}-6^{\prime \prime}\right), 17.4\left(\mathrm{C}-6^{\prime \prime \prime}\right)$.

\subsubsection{Quercetin 3-O-[ $\alpha$-L-rhamnopyranosyl $(1 \rightarrow 2)]-\beta$-D-xylopyranoside (52)}

Yellow powder; ${ }^{1} \mathrm{H}-\mathrm{NMR}\left(\mathrm{CD}_{3} \mathrm{OD}, 500 \mathrm{MHz}\right) \delta 7.59\left(1 \mathrm{H}, \mathrm{dd}, J=8.5,2.5 \mathrm{~Hz}, \mathrm{H}-6^{\prime}\right), 7.58(1 \mathrm{H}, \mathrm{d}$, $\left.J=2.5 \mathrm{~Hz}, \mathrm{H}-2^{\prime}\right), 6.87\left(1 \mathrm{H}, \mathrm{d}, J=8.5 \mathrm{~Hz}, \mathrm{H}-5^{\prime}\right), 6.34(1 \mathrm{H}, \mathrm{d}, J=2.0 \mathrm{~Hz}, \mathrm{H}-8), 6.16(1 \mathrm{H}, \mathrm{d}, J=2.0 \mathrm{~Hz}, \mathrm{H}-6)$, $5.59\left(1 \mathrm{H}, \mathrm{d}, J=7.0 \mathrm{~Hz}, \mathrm{H}-1^{\prime \prime}\right), 5.02\left(1 \mathrm{H}, \mathrm{d}, J=1.0 \mathrm{~Hz}, \mathrm{H}-1^{\prime \prime \prime}\right), 4.08\left(1 \mathrm{H}, \mathrm{qd}, J=10.0,6.0 \mathrm{~Hz}, \mathrm{H}-5^{\prime \prime \prime}\right), 4.00$ $\left(1 \mathrm{H}, \mathrm{dd}, J=3.5,1.0 \mathrm{~Hz}, \mathrm{H}-2^{\prime \prime \prime}\right), 3.79\left(1 \mathrm{H}, \mathrm{dd}, J=9.5,3.5 \mathrm{~Hz}, \mathrm{H}-3^{\prime \prime \prime}\right), 3.75\left(1 \mathrm{H}, \mathrm{dd}, J=12.5,4.5 \mathrm{~Hz}, \mathrm{H}-5^{\prime \prime} \mathrm{b}\right)$, $3.70\left(1 \mathrm{H}, \mathrm{dd}, J=9.0,7.0 \mathrm{~Hz}, \mathrm{H}-2^{\prime \prime}\right), 3.51\left(1 \mathrm{H}, \mathrm{m}, \mathrm{H}-4^{\prime \prime}\right), 3.51\left(1 \mathrm{H}, \mathrm{m}, \mathrm{H}-3^{\prime \prime}\right), 3.36(1 \mathrm{H}, \mathrm{dd}, J=10.0,9.5$ $\left.\mathrm{Hz}, \mathrm{H}-4^{\prime \prime \prime}\right), 3.10\left(1 \mathrm{H}, \mathrm{dd}, J=12.5,9.0 \mathrm{~Hz}, \mathrm{H}-5^{\prime \prime} \mathrm{a}\right), 1.07$ (3H, d, $\left.J=6.0 \mathrm{~Hz}, \mathrm{CH}_{3}-6^{\prime \prime \prime}\right) ;{ }^{13} \mathrm{C}-\mathrm{NMR}\left(\mathrm{CD}_{3} \mathrm{OD}\right.$, $125 \mathrm{MHz}) \delta 179.1$ (C-4), 167.5 (C-7), 163.1 (C-5), 158.5 (C-9), 158.4 (C-2), 149.8 (C-4'), 146.2 (C-3'), 134.4 (C-3), $123.3\left(\mathrm{C}-6^{\prime}\right), 123.2\left(\mathrm{C}-1^{\prime}\right), 117.0\left(\mathrm{C}-2^{\prime}\right), 116.0\left(\mathrm{C}-5^{\prime}\right), 105.4(\mathrm{C}-10), 102.7\left(\mathrm{C}-1^{\prime \prime \prime}\right), 101.3\left(\mathrm{C}-1^{\prime \prime}\right), 100.3$ (C-6), 95.0 (C-8), 79.6 (C-2 $\left.2^{\prime \prime}\right), 77.9\left(\mathrm{C}-3^{\prime \prime}\right), 74.1\left(\mathrm{C}-4^{\prime \prime \prime}\right), 72.4\left(\mathrm{C}-3^{\prime \prime \prime}\right), 72.3\left(\mathrm{C}-2^{\prime \prime \prime}\right), 71.5\left(\mathrm{C}-4^{\prime \prime}\right), 70.1\left(\mathrm{C}-5^{\prime \prime \prime}\right)$, $67.1\left(\mathrm{C}-5^{\prime \prime}\right), 17.6\left(\mathrm{C}-6^{\prime \prime \prime}\right)$.

\subsection{Anti-Inflammatory Bioactivity Examination}

The human neutrophils study (No. 1612200032) was approved by the Chang Gung Memorial Hospital Institutional Review Board (Taoyuan, Taiwan) and was conducted according to the Declaration of Helsinki (2013). The examination for the superoxide anion and elastase release inhibition was based on the superoxide dismutase (SOD)-inhibitable reduction of ferricytochrome c 
and degranulation of azurophilic granules as reported [67]. The experimental details were attached in the file of Supplementary Materials.

Supplementary Materials: The following are available online, S1: Extraction and isolation schemes; S2: Anti-inflammatory bioactivity experimental procedures; Figures S1-S14: 1D, 2D-NMR and MS spectra of new compounds 1 and 2; Figures S15-S18: ${ }^{1} \mathrm{H}$ - and ${ }^{13} \mathrm{C}-\mathrm{NMR}$ spectra of compounds $\mathbf{5 1}$ and $\mathbf{5 2}$.

Author Contributions: Conceptualization, P.-C.K. and J.T.C.T.; Data curation and Investigation, Y.-C.L., M.-L.Y., and T.-Y.C.; Methodology, T.-L.H. and C.-C.C.; Resources, T.-D.T. and N.N.T.; Writing-original draft, Y.-C.L.; Writing-review \& editing, P.-C.K. and J.T.C.T. All authors read and approved the final manuscript.

Funding: This research is sponsored by the Ministry of Science and Technology (MOST), Taiwan, granted to P.-C.K. and J.T.-C.T. The authors are also thankful for partial financial support from Chang Gung Memorial Hospital (CMRPF1G0241 3, CMRPF1F0061 3, and BMRP450 granted to T.-L.H.).

Acknowledgments: We appreciate T.S. Wu's valuable suggestions.

Conflicts of Interest: The authors declare no conflict of interest.

\section{References}

1. Sukumaran, S.; Kiruba, S.; Mahesh, M.; Nisha, S.R.; Miller, P.Z.; Ben, C.P.; Jeeva, S. Phytochemical consti-tuents and antibacterial efficacy of the flowers of Peltophorum pterocarpum (DC.) Baker ex Heyne. Asian Pac. J. Trop. Med. 2011, 4, 735-738. [CrossRef]

2. Manaharan, T.; Teng, L.L.; Appleton, D.; Ming, C.H.; Masilamani, T.; Palanisamy, U.D. Antioxidant and antiglycemic potential of Peltophorum pterocarpum plant parts. Food Chem. 2011, 129, 1355-1361. [CrossRef]

3. Bizimenyera, E.S.; Aderogba, M.A.; Eloff, J.N.; Swan, G.E. Potential of neuroprotective antioxidant-based therapeutics from Peltophorum africanum Sond.(Fabaceae). Afr. J. Trad. CAM 2007, 4, 99-106. [CrossRef]

4. Dandapat, R.; Jena, B.S.; Negi, P.S. Antimutagenic and antibacterial activities of Peltophorum ferrugineum flower extracts. Asian Pac. J. Trop. Dis. 2012, 2, S778-S782. [CrossRef]

5. Jain, S.C.; Pancholi, B.; Jain, R. Antimicrobial, free radical scavenging activities and chemical composition of Peltophorum pterocarpum Baker ex K. Heyne stem extract. Der. Pharm. Chem. 2012, 4, 2073-2079.

6. Jain, S.C.; Pancholi, B.; Jain, R. Peltophorum pterocarpum (DC.) Baker ex. K. Heyne flowers: Antimicrobial and antioxidant efficacies. J. Med. Plants Res. 2011, 5, 274-280. [CrossRef]

7. Raj, M.K.; Duraipandiyan, V.; Agustin, P.; Ignacimuthu, S. Antimicrobial activity of bergenin isolated from Peltophorum pterocarpum DC. flowers. Asian Pac. J. Trop. Biomed. 2012, 2, S901-S904. [CrossRef]

8. Lam, S.K.; Ng, T.B. First report of an antifungal amidase from Peltophorum pterocarpum. Biomed. Chromatogr. 2010, 24, 458-464. [CrossRef] [PubMed]

9. Manosroi, J.; Boonpisuttinant, K.; Manosroi, W.; Manosroi, A. Anti-proliferative activities on HeLa cancer cell line of Thai medicinal plant recipes selected from MANOSROI II database. J. Ethnopharmacol. 2012, 142, 422-431. [CrossRef] [PubMed]

10. Raj, M.K.; Balachandran, C.; Duraipandiyan, V.; Agastian, P.; Ignacimuthu, S.; Vijayakumar, A. Isolation of terrestribisamide from Peltophorum pterocarpum (DC.) Baker ex. K. Heyne and its antimicrobial, antioxidant, and cytotoxic activities. Med. Chem. Res. 2013, 22, 3823-3830.

11. Polasek, J.; Queiroz, E.F.; Marcourt, L.; Meligova, A.K.; Halabalaki, M.; Skaltsounis, A.L.; Alexis, M.N.; Prajogo, B.; Wolfender, J.L.; Hostettmann, K. Peltogynoids and 2-phenoxychromones from Peltophorum pterocarpum and evaluation of their estrogenic activity. Planta Med. 2013, 79, 480-486. [CrossRef] [PubMed]

12. Bizimenyera, E.S.; Githiori, J.B.; Swan, G.E.; Eloff, J.N. In vitro ovicidal and larvicidal activity of the leaf, bark and root extracts of Peltophorum africanum Sond. (Fabaceae) on Haemonchus contortus. J. Anim. Vet. Adv. 2006, 5, 608-614.

13. Bizimenyera, E.S.; Meyer, S.; Naidoo, V.; Eloff, J.N.; Swan, G.E. Efficacy of Peltophorum africanum Sond. (Fabaceae) extracts on Haemonchus contortus and Trichostrongylus colubriformis in sheep. J. Anim. Vet. Adv. 2008, 7, 364-371.

14. Islam, M.S.; Ali, S.; Rahman, M.; Islam, R.; Ali, A.; Azad, A.K.; Islam, M.R. Antidiabetic, cytotoxic activities and phytochemical screening of Peltophorum pterocarpum (DC.) K. Heyne root. J. Med. Plants Res. 2011, 5, $3745-3750$. 
15. Raju, B.; Vijaya, C.; Ramu, A. Evaluation of cardiotonic activity of Peltophorum pterocarpum. Int. J. Phytopharmacol. 2011, 2, 1-6.

16. Biswas, K.; Kumar, A.; Babaria, B.A.; Prabhu, K.; Setty, S.R. Hepatoprotective effect of leaves of Peltophorum pterocarpum against paracetamol induced acute liver damage in rats. J. Basic Clin. Pharm. 2010, 1, 10-15.

17. Agrawal, S.; Agarwal, S.S. Preliminary observations on leukaemia specific agglutinins from seeds. Indian J. Med. Res. 1990, 92, 38-42. [PubMed]

18. Kikuzaki, H.; Kayano, S.; Fukutsuka, N.; Aoki, A.; Kasamatsu, K.; Yamasaki, Y.; Mitani, T.; Nakatani, N. Abscisic acid related compounds and lignans in prunes (Prunus domestica L.) and their oxygen radical absorbance capacity (ORAC). J. Agric. Food Chem. 2004, 52, 344-349. [CrossRef]

19. Yu, Q.; Otsuka, H.; Hirata, E.; Shinzato, T.; Takeda, Y. Turpinionosides A-E: Megastigmane glucosides from leaves of Turpinia ternata Nakai. Chem. Pharm. Bull. 2002, 50, 640-644. [CrossRef]

20. Busch, J.; Grether, Y.; Ochs, D.; Séquin, U. Total synthesis and biological activities of (+)- and (-)-boscialin and their 1'-epimers. J. Nat. Prod. 1998, 61, 591-597. [CrossRef]

21. Takeda, Y.; Okada, Y.; Masuda, T.; Hirata, E.; Shinzato, T.; Takushi, A.; Yu, Q.; Otsuka, H. New megastigmane and tetraketide from the leaves of Euscaphis japonica. Chem. Pharm. Bull. 2000, 48, 752-754. [CrossRef] [PubMed]

22. Wang, C.Y.; Liu, X.; Guo, L.M.; Shao, C.L.; Fang, Y.C.; Wei, Y.X.; Zheng, C.J.; Gu, Q.Q.; Zhu, W.M.; Guan, H.S. Two new natural keto-acid derivatives from Sargassum pallidum. Chem. Nat. Compd. 2010, 46, 292-294. [CrossRef]

23. Takeshige, Y.; Kawakami, S.; Matsunami, K.; Otsuka, H.; Lhieochaiphant, D.; Lhieochaiphant, S. Oblongionosides $\mathrm{A}-\mathrm{F}$, megastigmane glycosides from the leaves of Croton oblongifolius Roxburgh. Phytochemistry 2012, 80, 132-136. [CrossRef] [PubMed]

24. Chen, C.Y.; Chang, F.R.; Teng, C.M.; Wu, Y.C. Cheritamine, a new N-fatty acyl tryptamine and other constituents from the stems of Annona cherimola. J. Chin. Chem. Soc. 1999, 46, 77-86. [CrossRef]

25. Kobayashi, S.; Ozawa, T.; Imagawa, H. Dehydrochorismic acid from Pinus densiflora pollen. Agric. Biol. Chem. 1982, 46, 845-847. [CrossRef]

26. Han, T.; Li, H.; Zhang, Q.; Zheng, H.; Qin, L. New thiazinediones and other components from Xanthium strumarium. Chem. Nat. Compd. 2006, 42, 567-570. [CrossRef]

27. Gopalakrishnan, S.; Subbarao, G.V.; Nakahara, K.; Yoshihashi, T.; Ito, O.; Maeda, I.; Ono, H.; Yoshida, M. Nitrification inhibitors from the root tissues of Brachiaria humidicola, a tropical grass. J. Agric. Food Chem. 2007, 55, 1385-1388. [CrossRef]

28. Laurent, P.; Lebrun, B.; Braekman, J.C.; Daloze, D.; Pasteels, J.M. Biosynthetic studies on adaline and adalinine, two alkaloids from ladybird beetles (Coleopteral: Coccinellidae). Tetrahedron 2001, 57, 3403-3412. [CrossRef]

29. Chung, C.P.; Hsia, S.M.; Lee, M.Y.; Chen, H.J.; Cheng, F.; Chan, L.C.; Kuo, Y.H.; Lin, Y.L.; Chiang, W. Gastroprotective activities of adlay (Coix lachryma-jobi L. var. ma-yuen Stapf) on the growth of the stomach cancer AGS cell line and indomethacin-induced gastric ulcers. J. Agric. Food Chem. 2011, 59, 6025-6033. [CrossRef]

30. Tan, J.; Bednarek, P.; Liu, J.; Schneider, B.; Svatoš, A.; Hahlbrock, K. Universally occurring phenylpropanoid and species-specific indolic metabolites in infected and uninfected Arabidopsis thaliana roots and leaves. Phytochemistry 2004, 65, 691-699. [CrossRef]

31. Manohar, C.; Rao, U.R.K.; Valaulikar, B.S.; Iyer, R.M. On the Origin of viscoelasticity in micellar solutions of cetyltrimethylammonium bromide and sodium salicylate. J. Chem. Soc. Chem. Commun. 1986, 5, 379-381. [CrossRef]

32. Begum, T.; Rahman, M.S.; Rashid, M.A. Phytochemical and biological investigations of Phyllanthus reticulates. Dhaka Univ. J. Pharm. Sci. 2006, 5, 21-23. [CrossRef]

33. Teh, C.H.; Morita, H.; Shirota, O.; Chan, K.L. 2,3-Dehydro- $4 \alpha$-hydroxylongilactone, a novel quassinoid and two known phenyl propanoids from Eurycoma longifolia Jack. Food Chem. 2010, 120, 794-798. [CrossRef]

34. Shen, Y.C.; Hsieh, P.W.; Kuo, Y.H. Neolignan glucosides from Jasminum urophyllum. Phytochemistry 1998, 48, 719-723. [CrossRef]

35. Shi, P.; Wang, L.; Chen, K.; Wang, J.; Zhu, J. Co(III)-catalyzed enaminone-directed C-H amidation for quinolone synthesis. Org. Lett. 2017, 19, 2418-2421. [CrossRef] 
36. Rodríguez, A.D.; Acosta, A.L. New cembranoid diterpenes and a geranylgeraniol derivative from the common Caribbean sea whip Eunicea succinea. J. Nat. Prod. 1997, 60, 1134-1138. [CrossRef]

37. Ahmad, F.; Ali, M.; Alam, P. New phytoconstituents from the stem bark of Tinospora cordifolia Miers. Nat. Prod. Res. 2010, 24, 926-934. [CrossRef]

38. Bibi, N.; Tanoli, S.A.K.; Farheen, S.; Afza, N.; Siddiqi, S.; Zhang, Y.; Kazmi, S.U.; Malik, A. In vitro antituberculosis activities of the constituents isolated from Haloxylon salicornicum. Bioorg. Med. Chem. Lett. 2010, 20, 4173-4176. [CrossRef]

39. Kuo, Y.H.; Chu, P.H. Studies on the constituents from the bark of Bauhinia purpurea. J. Chin. Chem. Soc. 2002, 49, 269-274. [CrossRef]

40. Katsui, N.; Matsue, H.; Hirata, T.; Masamune, T. Phytosterols and triterpenes in roots of the "kidney bean" (Phaseolus vulgaris L.). Bull. Chem. Soc. Jpn. 1972, 45, 223-226. [CrossRef]

41. Zhang, X.; Geoffroy, P.; Miesch, M.; Julien-David, D.; Raul, F.; Aoudé-Werner, D.; Marchioni, E. Gram-scale chromatographic purification of $\beta$-sitosterol synthesis and characterization of $\beta$-sitosterol oxides. Steroids 2005, 70, 886-895. [CrossRef]

42. Foley, D.A.; O'Callaghan, Y.; O'Brien, N.M.; McCarthy, F.O.; Maguire, A.R. Synthesis and characterization of stigmasterol oxidation products. J. Agric. Food Chem. 2010, 58, 1165-1173. [CrossRef] [PubMed]

43. Grishko, V.V.; Nogovitsina, E.M.; Ivshina, I.B. Optimization of conditions for biocatalytic production of stigmast-4-en-3-one. Chem. Nat. Compd. 2012, 48, 432-435. [CrossRef]

44. Ambrus, G.; Ilkőy, É.; Jekkel, A.; Horváth, G.; Böcskei, Z. Microbial transformation of $\beta$-sitosterol and stigmasterol into 26-oxygenated derivatives. Steroids 1995, 60, 621-625. [CrossRef]

45. Chang, Y.C.; Chang, F.R.; Wu, Y.C. The constituents of Lindera glauca. J. Chin. Chem. Soc. 2000, 47, $373-380$. [CrossRef]

46. Yue, J.M.; Chen, S.N.; Lin, Z.W.; Sun, H.D. Sterols from the fungus Lactarium volumus. Phytochemistry 2001, 56, 801-806. [CrossRef]

47. Fujimoto, H.; Nakamura, E.; Okuyama, E.; Ishibashi, M. Six immunosuppressive features from an ascomycete, Zopfiella longicaudata, found in a screening study monitored by immunomodulatory activity. Chem. Pharm. Bull. 2004, 52, 1005-1008. [CrossRef]

48. Chen, Y.K.; Kuo, Y.H.; Chiang, B.H.; Lo, J.M.; Sheen, L.Y. Cytotoxic activities of 9,11-dehydroergosterol peroxide and ergosterol peroxide from the fermentation mycelia of Ganoderma lucidum cultivated in the medium containing leguminous plants on Hep 3B cells. J. Agric. Food Chem. 2009, 57, 5713-5719. [CrossRef]

49. Buděšínský, M.; Vokáč, K.; Harmatha, J.; Cvačka, J. Additional minor ecdysteroid components of Leuzea carthamoides. Steroids 2008, 73, 502-514. [CrossRef]

50. Zhou, W.; Guo, S. Components of the sclerotia of Polyporus umbellatus. Chem. Nat. Compd. 2009, 45, 124-125. [CrossRef]

51. Kuo, Y.H.; Yeh, M.H. Chemical constituents of heartwood of Bauhinia purpurea. J. Chin. Chem. Soc. 1997, 44, 379-383. [CrossRef]

52. Wu, Z.H.; Iiu, T.; Gu, C.X.; Shao, C.L.; Zhou, J.; Wang, C.Y. Steroids and triterpenoids from the brown alga Kjellmaniella crassifolia. Chem. Nat. Compd. 2012, 48, 158-160. [CrossRef]

53. Khan, A.Q.; Ahmed, Z.; Kazmi, S.N.H.; Malik, A.; Afza, N. The structure and absolute configuration of cyclotirucanenol, a new triterpene from Euphorbia tirucalli Linn. Z. Naturforsch. B 1988, 43B, 1059-1062. [CrossRef]

54. Ayatollahi, A.M.; Ghanadian, M.; Afsharypuor, S.; Mesaik, M.A.; Abdalla, O.M.; Shahlaei, M.; Farzandi, G.; Mostafavi, H. Cycloartanes from Euphorbia aellenii Rech. f. and their antiproliferative activity. Iran. J. Pharm. Res. 2011, 10, 105-112. [PubMed]

55. Lee, C.K.; Chang, M.H. The chemical constituents from the heartwood of Eucalyptus citriodora. J. Chin. Chem. Soc. 2000, 47, 555-560. [CrossRef]

56. Yang, N.Y.; Tao, W.W.; Duan, J.A. Antithrombotic flavonoids from the faeces of Trogopterus xanthipes. Nat. Prod. Res. 2010, 24, 1843-1849. [CrossRef]

57. Kwon, D.J.; Bae, Y.S. Chemical constituents from the stem bark of Acer barbinerve. Chem. Nat. Compd. 2011, 47, 636-638. [CrossRef]

58. Luyen, B.T.L.; Tai, B.H.; Thao, N.P.; Eun, K.J.; Cha, J.Y.; Xin, M.J.; Lee, Y.M.; Kim, Y.H. Anti-inflammatory components of Euphorbia humifusa Willd. Bioorg. Med. Chem. Lett. 2014, 24, 1895-1900. [CrossRef] 
59. Chang, Y.; Zhang, P.; Zhang, X.; Chen, J.; Rausch, W.D.; Gula, A.; Bao, B. Cytotoxic activities of flavonoids from a traditional Mongolian medicinal herb Clematis aethusifolia Turcz. Nat. Prod. Res. 2017, 31, 1223-1227. [CrossRef]

60. Madikizela, B.; Aderogba, M.A.; Van Staden, J. Isolation and characterization of antimicrobial constituents of Searsia chirindensis L. (Anacardiaceae) leaf extracts. J. Ethnopharmacol. 2013, 150, 609-613. [CrossRef]

61. Rastrelli, L.; Saturnino, P.; Schettino, O.; Dini, A. Studies on the constituents of Chenopodium pallidicaule (Cañihua) seeds. Isolation and characterization of two new flavonol glycosides. J. Agric. Food Chem. 1995, 43, 2020-2024. [CrossRef]

62. Seshadri, T.R.; Vydeeswaran, S. Chrysoeriol glycosides and other flavonoids of Rungia repens flowers. Phytochemistry 1972, 11, 803-806. [CrossRef]

63. Olennikov, D.N.; Kashchenko, N.I. Calendosides I-IV, new quercetin and isorhamnetin rhamnoglucosides from Calendula officinalis. Chem. Nat. Compd. 2014, 50, 633-637. [CrossRef]

64. Phechrmeekha, T.; Sritularak, B.; Likhitwitayawuid, K. New phenolic compounds from Dendrobium capillipes and Dendrobium secundum. J. Asian Nat. Prod. Res. 2012, 14, 748-754. [CrossRef]

65. Yildiz, I.; Sen, O.; Erenler, R.; Demirtas, I.; Behcet, L. Bioactivity-guided isolation of flavonoids from Cynanchum acutum L. subsp. sibiricum (willd.) Rech. f. and investigation of their antiproliferative activity. Nat. Prod. Res. 2017, 31, 2629-2633.

66. Leite, J.P.V.; Rastrelli, L.; Romussi, G.; Oliveira, A.B.; Vilegas, J.H.Y.; Vilegas, W.; Pizza, C. Isolation and HPLC quantitative analysis of flavonoid glycosides from Brazilian beverages (Maytenus ilicifolia and M. aquifolium). J. Agric. Food Chem. 2001, 49, 3796-3801. [CrossRef]

67. Yu, H.P.; Hsieh, P.W.; Chang, Y.J.; Chung, P.J.; Kuo, L.M.; Hwang, T.L. 2-(2-Fluoro-benzamido)benzoate ethyl ester (EFB-1) inhibits superoxide production by human neutrophils and attenuates hemorrhagic shock-induced organ dysfunction in rats. Free Radic. Biol. Med. 2011, 50, 1737-1748. [CrossRef]

68. Chen, C.Y.; Liaw, C.C.; Chen, Y.H.; Chang, W.Y.; Chung, P.J.; Hwang, T.L. A novel immunomodulatory effect of ugonin $U$ in human neutrophils via stimulation of phospholipase C. Free Radic. Biol. Med. 2014, 72, 222-231. [CrossRef]

69. Pham, C.T.N. Neutrophil serine proteases: Specific regulators of inflammation. Nat. Rev. Immunol. 2006, 6, 541-550. [CrossRef]

Sample Availability: Samples of all the isolated compounds are available from the authors.

(C) 2019 by the authors. Licensee MDPI, Basel, Switzerland. This article is an open access article distributed under the terms and conditions of the Creative Commons Attribution (CC BY) license (http://creativecommons.org/licenses/by/4.0/). 